\title{
NRARP wt Allele
}

National Cancer Institute

\section{Source}

National Cancer Institute. NRARP wt Allele. NCI Thesaurus. Code C113610.

Human NRARP wild-type allele is located in the vicinity of 9q34.3 and is approximately 3 $\mathrm{kb}$ in length. This allele, which encodes Notch-regulated ankyrin repeat-containing protein, is involved in both endothelial cell proliferation and Notch signaling pathways. 